\title{
The Semiotic Landscape of Volgograd in the Context of Urban Communication Studies
}

\author{
Olga A. Leontovich ${ }^{\mathrm{a}, \mathrm{b} *}$ \\ ${ }^{a}$ Volgograd State Socio-Pedagogical University \\ 27 Lenin, Volgograd, 400066, Russia \\ ${ }^{b}$ Tianjin Foreign Studies University \\ No. 117 Machang Road, Tianjin, China
}

Received 05.12.2018, received in revised form 28.12.2018, accepted 11.01.2019

The aim of the paper is to investigate how urban semiotic signs construct the image of Volgograd as a non-capital city, which is in many ways representative of the current social processes in Russia. The study is done from the perspective of urban communication studies. The interdisciplinary approach is elucidated through the use of the theoretical frameworks of symbolic interactionism and critical discourse analysis, in combination with the research instruments of sociolinguistics, semiotics and ethnography of communication. The investigation shows in what way the semiotic landscape of Volgograd is created by means of verbal and nonverbal signs reflecting the city's historical memories, its cultural heritage and globalization tendencies. The emergence of new creative forms of communication, such as anti-cafés, "posidelki", "kvartirniki", etc., brings about changes in discourse patterns and vocabulary. Social activism based on "bottom-up" information flows produces new forms of urban communication symbolizing the growth of a new generation of the city-dwellers.

Keywords: urban communication, sociolinguistics, semiotic landscape, historical memories, cultural heritage, social activism, anti-café, verbal and nonverbal signs.

The reported study was funded by the Russian Foundation for Basic Research according to the research project No. 17-29-09114.

Research area: philology.

Citation: Leontovich, O.A. (2019). The semiotic landscape of Volgograd in the context of urban communication studies. J. Sib. Fed. Univ. Humanit. soc. sci., 12(1), 97-105. DOI: 10.17516/1997-1370-0382.

(C) Siberian Federal University. All rights reserved

* Corresponding author E-mail address: E-mail: olgaleo@list.ru

ORCID: 0000-0002-0972-4609

This work is licensed under a Creative Commons Attribution-NonCommercial 4.0 International License (CC BY-NC 4.0). 


\section{Introduction}

The present paper is part of a broader research project "Language of a Big City: Media Urban Discourse in Russia and China" carried out by a group of scholars from Volgograd State Socio-Pedagogical University (VSPU) on the example of Volgograd (Russia) and Tianjin (China). We have deliberately chosen two non-capital cities, which are in many ways a better representation of the current social processes than the westernized capitals. Alongside with the adoption of modern globalization tendencies, they still preserve linguistic and cultural traditions, to a certain extent counterbalancing cosmopolitanism. In this paper, we discuss how historical memories, cultural heritage, globalization tendencies and local trends are conceptualized in the semiotic landscape of Volgograd and realized in both verbal and nonverbal communication practices.

\section{Background, methodology and key principles}

The rapid development of big cities, variability of social life and its semiotic personifications account for the growing popularity of urban communication studies as a discipline. Urban communication acts as a framework, which shapes people's memories, perceptions, mediation and self-identification patterns.

Urban communication scholars view the city as "an organic interactional arena", which makes use of numerous semiotic systems - linguistic, symbolic, visual, as well as "materiality and textures", "rhythms, and other 'modes' including but not limited to sound and smell". They point out that cities act as "producers and products of particular practices, interactions, and narratives" (Aiello, Tosoni, 2016: 1257-1258) and believe that communication patterns between individuals and communities, different uses of media and technology, aesthetics and representation are nowadays fundamental to urban planning and policymaking. Due to these factors, urban communication research "has become central to making rather than just studying cities" (Aiello, Tosoni, 2016: 1253).

The urban landscape is researched from the perspective of: 1) its material parameters: toponymy, architecture, arrangement and modification of public and private space; 2) uses of space for living, working and recreation; 3) formal and informal social practices and networks; 4) social stratification based on ethnicity, income, education, age, gender and its reflexion in urban communication practices; 5) safety and dangers associated with urban life; 6) common patterns of communicative behaviour and deviations from the norm; 7) use of verbal and nonverbal signs to transmit a variety of meanings, etc. 
Scholars investigate different media (street names, transportation, markets, cafés, restaurants, food, shops, supermarkets, events, music, etc.), as well as people's relationship, different forms of their interaction, social and cultural consequences of urban communication development. In our study, we proceed from the assumption that city life is largely dependent on national and global social dynamics, circulation of symbolic meanings, mechanisms of knowledge transfer, migration, travel, communal media consumption, etc. The interdisciplinary approach is elucidated through the use of the theoretical frameworks of symbolic interactionism and critical discourse analysis, in combination with the research instruments of sociolinguistics, semiotics and ethnography of communication (Leontovich, 2018: 207).

The material of the research has been collected from observation, surveys, Internet sites, social networks, TV programs and advertising. It has been supplemented by over 300 images of city signs, which were obtained as a result of the project "The City is Speaking to Me" assigned to graduate students of VSPU. The analysis of the material "at the intersection of the city as content and the city as context" (Aiello, Tosoni, 2016: 1257-1258) gives us an opportunity to see how urban semiotics constructs Volgograd's image and creates "the meaningful identities" (Dickinson, 1997: 5) of its inhabitants.

\section{Perspective 1. Historical memories}

Volgograd's semiotic landscape embodies a multidimensional relationship between war and peace, the past, present and future, memories and contemporary issues. As G. Mondan puts it, "city streets are texts that are written in words, images, and architectural features" (Mondan, 2017: 15).

In his essay "Memories for Sale...", G. Dickinson writes about "memory encoded in the landscapes" (Dickinson, 1997: 20), which "are used for creating identities", placing "both the landscapes and individuals within a stabilizing and authenticating past" (Ibid: 1).

The memories and narratives about World War II are what shapes Volgograd's identity giving it a face of its own. Unlike ancient Russian and foreign cities, e. g. Pasadena in California described by Dickinson (Ibid), it does not create an atmosphere of nostalgia, but is rather a tribute to human suffering. There are virtually no old buildings, as they were all destroyed during the war - the inhabitants are cut from the past beyond the year of 1942 when the Stalingrad Battle began.

During its history the city had three different names. It was founded in 1589 as a stronghold called Tsaritsyn - which on the surface looks like an allusion to Tsaritsa 
(or Tzarina - Russian queen), but in reality stems from the Tartar "yellow sand". In 1925 the city was renamed Stalingrad (evidently, after Stalin). This name is well known because of the Stalingrad battle (1942 - 43), the turning point of World War II. In 1961, due to Nikita Khrushchev's policy of denouncing Stalin as a tyrant and dictator, it was renamed Volgograd.

All the three names are present in Volgograd's urban landscape and act as temporal landmarks sustaining people's memories and defining their cultural values. "Tsaritsyn" is used in the names of a big shopping centre and the local opera. The name "Stalingrad" is nowadays connected not so much with Stalin, but rather with the emotion-laden memories of the Stalingrad battle, which are also reflected in toponyms (names of districts, squares and streets), as well as numerous material objects. The city landscape is dominated by the 185-meter-tall statue of the Motherland, which has acquired a strong symbolic meaning and is omnipresent on all the city's memorabilia. It is situated on top of Mamayev Kurgan (or Mamayev Hill) - the city's highest point originally named after Khan Mamay, $14^{\text {th }}$ century leader of the Tartar Golden Horde; nowadays, however, the site is better known in connection with the Stalingrad battle. Both the statue and the Hill are linguistically and visually the semiotic core of the city's image.

The name "Volgograd", in its turn, is associated with the present, most recently with the FIFA World Cup 2018, which has become an important historical landmark and image maker of the city. It was marked by the construction of a huge Arena stadium, a new park, fan zone, new cafés and restaurants and the emergence of new products carrying the World Cup 2018 symbols (official logo and wolf Zabivaka), as well as local dishes specially intended for the football fans. All the three names, as well as visual images, are exploited by the producers of local goods and foodstuffs, used on chocolate boxes and in brand names of different goods, appear on numerous souvenirs, T-shirts, postcards, etc.

\section{Perspective 2. Cultural Heritage}

The semiotic landscape of Volgograd is greatly influenced by the strong nostalgia for old Russia and the axiological value of Russian culture. It is cultivated through the images of the Don Cossacks - an ethnic group, which originally, during the time of Ivan the Terrible, protected the Russian Southern borders from nomads. Those images are promoted through folk song-and-dance groups, as well local products, such as chocolates Don-batyushka (Father Don), Aksinya (character of the famous 
novel "Quiet Flows the Don"), restaurant Gulyai-Pole (representation of the Cossack freedom), etc.

Unlike in Soviet times, communist propaganda is no longer present in the urban landscape and food industry. An interesting exception is the well-known chocolate factory Konfil (Russian abbreviation of "Confectionary named after Lenin"). However, nowadays consumers hardly know the origin of the name, which is used without any reference to Lenin.

\section{Perspective 3. Globalization}

The features of globalization in Volgograd are similar to those all over the world, where both visual images and language are "inscribed onto environments" and "reflect broader sociolinguistic, socio-cultural and political realities" (Jones, 2017: 7). The present-day city's landscape is defined by multilingualism, hybridization and commodification. As in many other cities, the English, French, Italian and other foreign signs on shops, cafés, restaurants, cinemas, spas, etc. are not so much aimed at foreign customers, but rather at local citizens. This is a reflexion of the Russian mixed attitude towards the West - on the one hand, a hurt feeling because of the political turmoil, and on the other - high prestige and idealized perception of the Western lifestyle, which adds foreign flavour to public spaces if they bear names written in the Latin alphabet. Globalization is represented in different linguistic forms:

- use of foreign words proper: Hungry, Redwood Bar, Le Balcon, Rivoli;

- foreign words written in Cyrillic alphabet: Европа Сити Молл, о'кей, Парк Хаус;

- Russian words written in Latin alphabet: Vozduh, Marusya, Tsiryulnik, Nosorog;

- different kinds of hybrids: рубль-бум (rouble-boom), Volga Hall, KOФEIN, Probka Hall, Malina fashion butik, Жap Пuщ̧uฺ (Zhar Pizza), etc.

\section{Perspective 4. Social activism}

The study shows that urban communication is formed under the influence of two opposite information flows:

1) “top-down" represented by centralized media, which predominantly possesses characteristics typical of globalized media (use of aggressive communication strategies, conflict, scandal, etc. aimed at attracting the attention of a wide audience);

2) "bottom-up" (interpersonal and social group interaction); though strongly affected by mass media, it displays positive features as a way of counterbalancing the flow of negativity: 
- grassroots initiative;

- growth of face-to-face rather than computer-mediated communication (people tend to go out to public places rather than interact through the Internet);

- emphasis on intellectual and cultural activities.

A. Kvyat, who has done a lot of research of Russian urban communication, writes that modern Russia can be seen as a country of two separate communicative cultures, one of which - vertical - is formed by TV and is one-way, monological communication of the state with society. The second culture rooted in social media is chaotic, non-linear, acentric, organized along the horizontal lines of social networking. It is based on self-organization, initiative and media activism of common people (Kvyat, 2013: 251).

Social activism in Volgograd is represented in both globalized and specifically Russian communication forms. The international ones include debates, table games, improvised dance floors for younger or older people, express dating, business clusters, etc. Specifically Russian are such hybrid spaces as anti-cafés, "posidelki", "kvartirniki", etc.

Anti-café is a form of communication which originated in Russia and is described by A. Kvyat as "a place between a coffeehouse and a social club where people pay only for the time they spend there, while tea, coffee, and some snacks are free". The activities are centred on communication and smart entertainment, such as table games, film screenings, concerts, performances, exhibitions, lectures, and workshops. It is not allowed to drink alcohol and smoke, but visitors can bring their own food, heat it in a microwave or even cook it in the kitchen (Kvyat, 2013: 3). Anti-café is positioned as one of the so called 'third places', the 'first place' being home, the 'second place' work, and the 'third place' - informal gathering spaces giving people an opportunity to socialize (Oldenburg, 1989). Volgograd has a number of anti-cafés, the names of which reflect the innovative and challenging form of communication itself: 4RooM, CyberTime, ДК Time, O2 lounge\&hookah, Kafedra, etc.

The emergence of new forms of interaction, partially due to globalization and multilingualism, brings about changes in discourse patterns and vocabulary, e. g.:

1) acquisition of foreign words nominating the new communication formats, such as флэшмоб (flashmob), пипл фэст (people fest), печа-куча (pecha-kucha);

2) formation of hybrids denoting those formats and their participants: сальса вечеринка (salsa vecherinka = salsa party), художник-aymcaüдер (khudoznikoutsider $=$ artist outsider); 
3) extensive use of wordplay: Икра (name of 'creative space' based on the interplay of two words: igra-game and ikra-caviar), Котокафе Котейня (Котосаfе́ Koteinya - an interplay of three words: kot - cat, café and kofeinya-coffeehouse).

Social activism and the resulting changes in communication patterns symbolize the growth of a new generation, with its own outlook, perception of reality, understanding of its place in society and arrangement of urban space.

\section{Final considerations}

1. The constituent features of urban communication studies as a discipline acting as a context for this research can be summed up in the following way:

- the city is interpreted as a complex communicative system representing a variety of channels, forms and means of human interaction, "a text" in a broad sense of the word;

- special attention is given to the social aspect of communication and its impact on the formation of personal and collective identity of the city dwellers;

- the research is centered not on particular linguistic units and other semiotic signs, but a social problem that affects their use and dynamics (in our case - the factors which shape the city's image and its culture);

- an important place in the research belongs to semiotic signs and technological means of communication.

2. The semiotic landscape of Volgograd shaping its image is created by means of verbal and nonverbal signs reflecting the city's historical memories, its cultural heritage and globalization trends. Social activism based on "bottom-up" information flows produces new creative forms of urban communication symbolizing the emergence of a new generation of the city-dwellers.

\section{References}

Aiello, G., Tosoni, S. (2016). Introduction. Going About the City: Methods and Methodologies for Urban Communication Research. In International Journal of Communication, 10, 1252-1262.

Dickinson, G. (1997). Memories for Sale: Nostalgia and the Construction of Identity in Old Pasadena. In The Quarterly Journal of Speech, 83, 1, 1-27.

Jones, R.H. (2017). The City is Watching You. In Abstracts of the conference "City Talk: Urban Identities, Mobilities and Textualities". University of Bern, December 11-12, 2017, p. 7. 
Kvyat, A. (2015). Anti-café as a new type of urban public space: the case study of Ziferblat. University of Warwick, Department of Sociology, 30 p.

Kvyat, A.G. (2013). Novye kommunikativnye praktiki v rossijskih gorodah [New communication practices in Russian cities]. In Razvitie russkojazychnogo mediaprostranstva: kommunikacionnye $i$ eticheskie problemy [Development of the Russian-language media space: communication and ethical problems]. Moscow: Izdatel'stvo APK i PPRO, 2013, 351-360.

Leontovich, O.A. The All-Seeing Eye of the City from the Perspective of Urban Communication Studies. In Science Journal of VolSU. Linguistics. 2018. Vol. 17. No. 4, $206-213$.

Mondan, G. (2017). New Urban Chic: The Semiotic Landscape of Gentrification in US Cities. In Abstracts of the conference "City Talk: Urban Identities, Mobilities and Textualities”. University of Bern, December 11-12, 2017, p. 15.

Oldenburg, R. (1989). The Great Good Place: Cafés, Coffee Shops, Bookstores, Bars, Hair Salons, and Other Hangouts at the Heart of a Community. N.Y.: Marlowe \& Company, 338 p.

\title{
Семиотический ландшафт Волгограда в контексте медиаурбанистики
}

\author{
О.А. Леонтович ${ }^{\mathrm{a}, \boldsymbol{0}}$ \\ ${ }^{a}$ Волгоградский государственный \\ социально-педагогический университет \\ Россия, 400066, Волгоград, пр. Ленина, 27 \\ ${ }^{6}$ Тяньцзиньский университет иностранных языков \\ Kumaü, Tianjin, Machang Road, No. 117
}

Цель статьи - рассмотреть роль семиотических знаков в конструировании образа Волгограда как нестоличного города, в значительной степени отражаютего тенденции соииального развития в российской городской среде. Исследование проводится с позищий медиаурбанистики - стремительно развивающегося научного направления. Междисииплинарный подход обеспечивается благодаря использованию теоретических положений символического интеракционизма и критического дискурс-анализа, а также методов сочиолингвистического, семиотического и этнографического анализа. Изучение семиотического ландшафта Волгограда показывает, как образ города создается с помощью вербальных и невербальных знаков, в которых концептуализируются историческая память, культурное наследие и глобализачионные тенденции. Возникновение новых креативных форм коммуникации, таких как антикафе, «посиделки», 
«квартирники» и т. д., приводит к изменению дискурсивных моделей и языка общения. Социальная активность, основанная на восходящих потоках информации, продуцирует новые формы медиаурбанистического дискурса, типичного для молодого поколения жителей крупных городов.

Ключевые слова: медиаурбанистика, социолингвистика, семиотический ландшафт, историческая память, культурное наследие, социальный активизм, антикафе, вербальные и невербальные знаки.

Исследование выполнено при финансовой поддержке РФФИ в рамках научного проекта № 17-29-09114.

Научная спещииальность: 10.00.00 - филологические науки. 